\title{
Pendidikan Akhlak dalam Karya Fiksi: Analisis Aspek Religius dalam Novel Sekayu Karya Nh. Dini
}

\author{
Syahdan \\ STIT Palapa Nusantara Lombok NTB \\ Email: syahdankbr@ymail.com \\ HP: 081803648316
}

\begin{abstract}
Abstrak: Tujuan dari penelitian ini adalah mendeskripsikan aspek religius yang terdapat di dalamnya. Manfaat yang diharapkan dapat memahami aspek religius yang terdapat dalam karya-karya sastra khususnya pada novel sekayu karya Nh. Dini, dan diharapkan juga sebagai acuan bagi peneliti selanjutnya. Penelitian ini bersifat deskrftif. Dan yang menjadi sumber data dalam penelitian ini dalam penelitian ini adalah novel sekayu karya Nh. Dini. Metode pengumpulan data yang digunakan adalah adalah studi pustaka dan metode dokumenter. Langkah-langkah dalam analisis data yakni meganalisi mengklasifkasi dan menginterpretasi. Berdasarkan hasil pembahasan, penelitian ini menyimpulkan bahwa aspek religius dalam novel tersebut adalah moral religius suatu bentuk pendidiakn akhlak dalam agama Islam, di antaranya: akhlak terhadap diri sendiri (sabar dan tabah dalam menerima ketentuan Tuhan), akhlak terhadap keluarga (berbakti kepada orang tua), akhlak terhadap masyarakat (tolong menolong, penyantun dan budi pekerti yang baik).

Key words: Religius, Novel Sekayu
\end{abstract}

\section{A. Latar Belakang}

Karya sastra lahir di tengah-tengah masyarakat dari hasil imajinasi pengarang serta refleksinya terhadap gejala-gejala sosial di sekitarnya. Oleh karena itu, kehadiran karya sastra merupakan bagian dari kehidupan masyarakat. Adanya imajinasi pada sebuah karya sastra akan menyebabkan karya sastra itu manjadi karya sastra yang imajinatif, yang di dalamnya berisikan pikiran, perasaan, ide dan harapan, yang telah terangkum menjadi satu dan dikemas dengan menggunakan bahasa yang indah sehingga menjadi sebuah karya sastra.

Keberadaan karya sastra sebagai bagian dari kebudayaan dan peradaban umat manusia, mengandung fungsi dan memiliki peranan penting, tidaklah terbatas pada hal-hal yang bersifat subyektif atau semata-mata berorientasi pada pribadi seorang sastrawan

Palapa: Jurnal Studi Keislaman dan Ilmu Pendidikan

Volume 5, Nomor 2, November 2017; p-ISSN 2338-2325; e-ISSN 2540-9697;138-148 
Salah satu bentuk karya sastra yang populer adalah novel. Novel merupakan sebuah struktur organisme yang kompleks, unik dan mengungkapkan sesuatu (lebih bersifat) secara tidak langsung. Novel tidak hanya sebagai bacaan di waktu senggang saja, namun juga bisa menjadi media transfer informasi dan pengalaman yang bisa juga dijadikan pelajaran atau acuan bagi pembaca karena berisi tentang banyak hal yang bisa dijadikan pembaca sebagai inpirasi dalam melakukan sesuatu yang secara tidak langsung akan turut mempengaruhi persepsi pembaca tentang pesan seperti pesan moral, pendidikan dan religiusitas yang ingin disampaikan penulis.

Ada banyak hal atau pesan yang terkandung dalam novel atau karya sastra tersebut yang ingin diungkapkan oleh penulis kepada pembaca seperti pesan moral, pendidikan, religiusitas yang secara tidak langsung akan membawa pembaca untuk lebih memahami hidup. Namun terkadang gaya bahasa yang digunakan membuat pembaca memiliki penafsiran yang berbeda mengenai karya sastra tersebut. Hal inilah antara lain yang menyebabkan sulitnya pembaca untuk menafsirkannya. Untuk itu diperlukan suatu upaya untuk dapat menjelaskannya dan biasanya hal itu disertai bukti-bukti hasil kerja analisis.

Seperti halnya novel lain, novel yang dianalisis dalam penelitian ini yakni Novel Sekayu karangan Nh. Dini memiliki banyak pesan dan amanat yang dapat diambil oleh pembaca. Novel ini menceritakan tentang kisah tokoh dalam kehidupannya, kegigihannya untuk maju bersama keluarganya meskipun tanpa kepala keluarga. Novel ini juga menceritakan tentang peran seorang ibu dalam membina anak-anaknya, kesederhanaan tokoh dan keluarganya dalam kehidupannya.

Berdasarkan hal-hal di atas, dipandang perlu dilakukan kegiatan penelitian untuk mengetaui pesan dan amanat apa saja yang ingin disampaikan penulis khususnya aspek religius terhadap karya sastra Novel "Sekayu” karya Nh. Dini dalam rangka menumbuhkan jiwa manusia yang humanistik yakni jiwa yang halus, manusiawi, berbudaya serta berpikir kritis.

Berdasarkan uraian di atas, rumusan masalah dalam penelitian ini adalah:

Bagaimanakah struktur Novel Sekayu karya Nh. Dini, dan Bagaimanakah aspek religius sebagai sebuah bentuk pesan pendidikan akhlak yang terdapat dalam Novel Sekayu karya Nh.Dini. adapun tujuan dalam penelitianini adalah untuk mendeskripsikan struktur dan aspek religius dalam Novel Sekayu karya Nh.Dini. 
Manfaat yang diharapkan dari penelitian ini adalah: Dapat digunakan untuk mengembangkan sikap kritis dan waspada bagi peneliti dalam memahami dan menyeleksi aspek religius yang terkandung dalam Novel Sekayu karya Nh.Dini, di samping itu diharapkan memberikan wawasan bagi peneliti, dan dapat menjadi acuan bagi peneliti selanjutnya.

\section{Tinjauan Pustaka}

\subsection{Konsep Dasar}

Dalam KBBI (1994), analisis adalah penyelidikan terhadap suatu peristiwa (karangan, perbuatan, dan sebagainya) untuk mengetahui keadaan yang sebenarnya (sebab musabab, duduk perkaranya, dan sebagainya). Menurut Salim dan Salim (1991), analisis dapat bermakna yaitu 1) penjabaran (pembentangan) sesuatu hal dan sebagainya setelah ditelaah secara seksama, 2) proses pemecahan masalah (melalui akal) ke dalam bagian-bagiannya berdasarkan metode yang konsisten untuk mencapai pengertian tentang prinsip-prinsip dasarnya, 3) penguraian karya sastra atas bagianbagian (unsur-unsur)nya untuk memahami hubungan antarbagian tersebut. Analisis sama dengan menganalisa dan mengandung pengertian yaitu penyelidikan, penguraian atas penemuan baik itu berupa tulisan, peristiwa, perilaku dan perbuatan yang bertujuan untuk mendapatkan keadaan yang sebenarnya (Anonim, 2002).

Dari penjabaran di atas dapat disimpulkan analisis bermakna suatu penguraian, penyelidikan, dan penjabaran dengan proses pemecahan suatu masalah atau objek kajian. Dan yang dimaksud peneliti dalam kajian ini adalah berkaitan dengan butir 7 yaitu penguraian karya sastra atas bagian-bagian (unsur-unsur)nya untuk memahami hubungan antarbagian tersebut. Jadi unsur-unsur yang diteliti dalam kajian ini adalah unsur-unsur yang ada pada Novel Sekayu karangan Nh. Dini.

Dalam KBBI (1994), aspek berarti; (1) tanda, (2) sudut pandangan, dan (3) kategori gramatikal verbal yang menunjukkan lama dan jenis perbuatan. Sedangkan religius dalam KBBI (1994) berarti bersifat religi; bersifat keagamaan; yang bersangkut-paut dengan religi. Berdasarkan kajian di atas aspek religius adalah aspekaspek yang mengiringi atau mengajarkan pembaca kepada konsep-konsep hubungan manusia dengan pencipta, dengan unsur ini maka dapat menjadi tuntutan bagi 
pembaca sastra untuk mencontoh atau tidak mencontoh kepada yang dicontohkan tokoh cerita.

\section{2 . Pengertian Novel}

Menurut Tarigan dalam Zulfahnur (1996) novel berasal dari kata latin "novellus" yang diturunkan dari kata "novelis" yang berarti baru: cerita yang baru muncul kemudian sesudah drama, puisi dan lain-lain. Pendapat yang hampir sama juga dikemukakan oleh Altenbernd dan Lewis dalam Nurgiantoro (1995) novel dapat diartikan prosa naratif yang bersifat imajiner, namun biasanya masuk akal dan mengandung kebenaran yang mendramatisasi hubungan-hubungan antara manusia. Sedangkan menurut Alwi (1994), novel merupakan karangan prosa yang panjang mengandung rangkaian cerita kehidupan seseorang dengan orang-orang di sekelilingnya dengan menonjolkan watak dan sifat setiap prilaku.

Secara umum dapat disimpulkan bahwa novel adalah reaktan imajinatif dan muncul karena adanya imajinasi pengarang melihat kenyataannya bahwa novel merupakan prosa yang panjang mengandung rangkaian cerita tentang kehidupan para tokoh yang bersifat representatif dalam suatu alur atau keadaan.

\section{3 . Religiusitas dalam Karya Sastra}

Wijaya dalam Nurgiantoro (1995) menegaskan bahwa religiusitas mengatasi atau lebih dalam dari agama yang tampak formal, resmi. Dengan demikian, religiusitas bukan hanya sehubungan ketaatan ritual atau hukum agama tetapi pada yang lebih mendalam, lebih mendasar dalam pribadi manusia. Religiusitas berkaitan dengan kebebasan orang untuk menjaga kualitas keberagamaannya jika dilihat dari dimensi yang paling dalam dan personal yang acap kali berada di luar kategori-kategori ajaran agama (Ratnawati, 2002)

Dari uraian di atas dapat disimpulkan bahwa religiusitas adalah suatu perasaan batin atau sikap personal yang ada hubungannya dengan Tuhan, rasio dan rasa manusiawi yang dirasakan manusia secara mendalam, hal itu antara lain adalah : 


\subsubsection{Akidah}

Akidah menurut arti harfiahnya adalah: ikatan. Menurut istilah yang sering dipakai adalah ilmu yang berhubungan dengan kepercayaan terhadap Allah, para malaikat, kitab-kitab yang diturunkan kepada utusannya (nabi-nabi), percaya kepada utusannya, percaya akan adanya hari akhirat, dan percaya kepada ketentuan Allah (taqdir). Istilah yang paling simpel adalah ilmu tentang sistem kepercayaan, keyakinan dan keimanan Islam (Harahap, 2002 : 1). Ahli lain seperti Azra (2002) menyatakan bahwa akidah merupakan ajaran tentang apa saja yang mesti dipercayai, diyakini dan dialami oleh setiap orang islam. Oleh karena itu, akidah merupakan kata dan simbol dasar islam yang pertama dan yang utama. Sedangkan menurut Hamka dalam Nurdin (1995) dengan memperhatikan arti etimologisnya, akidah yaitu mengikatkan hati dan perasaan dengan satu kepercayaan yang tidak bisa ditukarkan lagi dengan yang lain, sehingga jiwa dan raga, pikiran dan pandangan hidup terikat kuat pada-Nya.

Kata aqidah sering disebut dengan 'aqaid bentuk jamak dari aqidah, yakni ilmu i'tiqad karena ilmu yang dibicarakan dalam ilmu ini adalah soal-soal yang menyangkut i'tiqad (kepercayaan). Dalam memahami soal-soal i'tiqad dalam Islam, istilah-istilah yang dipakai dalam lingkungan ini sering disebut ushuluddin yang berasal dari kata ushul yang berarti pokok, dan ad-din berarti agama, maka ilmu ushuluddin adalah ilmu tentang pokok-pokok agama dan ilmu aqidah dinamakan ilmu ushuluddin. Di dalam ilmu ini dibicarakan soal-soal i'tiqad yang menjadi pokok bagi agama, yaitu : a) Kepercayaan yang bertalian dengan Ketuhanan. b) Kepercayaan yang bertalian dengan kenabian. c) Keprcayaan yang bertalian dengan soal-soal yang gaib (hari akhirat, syurga, neraka, dan lain-lain). d) Dan lain-lain soal kepercayaan (Abbas, 2004: 1).

Dari pendapat di atas disimpulkan bahwa akidah adalah keyakinan dasar yang menguatkan atau menyejukkan jiwa sehingga jiwa terbebas dari rasa kebimbangan atau keraguan, di dalam Islam disebut iman. Dan keyakinan yang menguatkan itu adalah : a). Ketauhidan yakni suatu kepercayaan atau keimanan yang menegaskan bahwa hanya Tuhan lah yang menciptakan, menentukan rezeki, maut, jodoh bahkan memberi hukuman (teguran atau ujian) serta mengatur alam semesta. Dan b) adalah iman terhadap takdir yakni kepercayaan yang benar terhadap takdir Tuhan ini akan memberikan sublime (nilai hidup yang tinggi) bagi seseorang akan menjadi 
pendorong untuk meraih hidup yang lebih baik. Seseorang yang mempercayai takdir Tuhan dengan sungguh-sungguh menerima keadaan dengan wajar dan bijaksana.

\subsubsection{Akhlak}

Akhlak berasal dari kata khalaqa dan akar kata kbuluqan (bahasa Arab) yang berarti: perangai, tabiat dan adat, atau dari kata khalqun (bahasa Arab), yang berarti kejadian buatan, atau ciptaan (Nurdin dkk, 1995). Secara lengkap akhlak juga sering disebut dengan moral, diartikan sebagai ajaran baik buruknya perbuatan dan kelakuan.

Menurut Al-Gazali dalam Paozan (1994) akhlak adalah hal ihwal yang melekat dalam jiwa daripadanya timbul perbuatan dengan mudah tanpa dipikirkan dengan teliti. Sedangkan Amin (2002) menjelaskan bahwa akhlak atau moral merupakan pendidikan jiwa agar jiwa seseorang dapat bersih dari sifat-sifat yang tercela dan dihiasi dengan sifat-sifat terpuji, seperti rasa persaudaraan dan saling tolongmenolong antarsesama manusia, sabar, tabah, belas kasihan, pemurah dan sifat-sifat terpuji lainnya.

Akhlak sering juga disebut dengan moral, diartikan sebagai ajaran baik buruk perbuatan dan atau kelakuan. Menurut Nurdin (1995) menyatakan bahwa akhlak adalah sistem nilai yang mangatur pola sikap dan tindakan manusia di atas bumi. Sistem nilai yang dimaksud adalah ajaran islam, dengan Al Qur'an dan Sunnah Rasul sebagai sumber nilainya serta ijtihad (hukum Islam) sebagai metode berpikir islami.

Dari beberapa pendapat di atas, dapat disimpulkan akhlak adalah tingkah laku, budi pekerti, yang melekat pada jiwa seseorang untuk melakukan suatu hal atau perbuatan antara lain yaitu : a). Pengabdian pada orang tua. Pengabdian kepada orang tua adalah salah satu prilaku yang tergolong akhlakul karimah (akhlak yang mulia). Dengan berbakti dan memuliakan serta menghormati ibu bapak adalah kewajiban semua anak. b).Sabar dan tabah dalam menerima ketentuan Tuhan. Sabar dan tabah dalam menerima ketentuan Tuhan adalah salah satu bagian dari prilaku yang terpuji dan menduduki tempat yang utama dalam menentukan kesempurnaan pribadi. 


\subsubsection{Syariat}

Dalam KBBI (1994), syariat berarti hukum agama (yang diamalkan menjadi perbuatan-perbuatan, upacara dan sebagainya) yang bertalian dengan agama Islam, yang baik akan dibalas dengan baik, jahat dibalas dengan jahat.

\section{Metode Penelitian}

\section{1 . Jenis Penelitian}

Penelitian yang akan dilakukan adalah penelitian yang bersifat deskriptif karena hasilnya akan berupa gambaran-gambaran berdasarkan fakta yang ada (obyektif), yang berusaha untuk menuturkan pemecahan masalah tentang data kemudian menarik kesimpulan yang berupa gambaran tentang sasaran penelitian berdasarkan data-data yang dihasilkan dapat mencerminkan kesimpulan yang sebenarnya. Penelitian ini pun bertujuan untuk memecahkan suatu masalah secara sistematis dan faktual mengenai fakta-fakta yang terdapat dalam novel Sekayu karya Nh. Dini

\section{2 . Data dan Sumber Data}

Yang menjadi data dalam penelitian ini adalah struktur objektif dan aspek religius yang terdapat dalam Novel Sekayu karya Nh. Dini. Sedangkan sumber data dalam penelitian ini adalah Novel Sekayu karya Nh. Dini. Untuk lebih jelasnya identitas novel yang dimaksud sebagai berikut:

- Judul : Sekayu

- Pengarang : Nh. Dini

- Penerbit : PT Gramedia Pustaka Utama

- Kota terbit : Jakarta

- Tahun terbit : 2004

- Ukuran buku : $14,1 \mathrm{~cm}$ x $21 \mathrm{~cm}$

- Ukuran ketikan :1 spasi

- Jumlah halaman : 181 halaman

- Jenis buku : novel

- Cetakan : : keenam Maret 2004

- Kulit muka: gambar rumah adat Jawa, sepasang pria dan wanita yang 
sedang menari dan seorang gadis dengan rambut berkepang yang bergambar besar.

- Warna kulit (sampul) : biru dengan judul Sekayu berwarna putih

- Desain sampul : Rahardjo S.

\section{3 . Metode Pengumpulan Data}

Teknik pengumpulan data yang digunakan dalam penelitian ini adalah sebagai berikut : a) Studi pustaka dilaksanakan untuk menemukan sumber-sumber acuan paling utama. Sumber acuan atau sumber pustaka yang dimaksud adalah buku-buku yang ada kaitannya dengan penelitian yang dilakukan. b) Metode dokumenter yaitu cara mengumpulkan data-data dan bahan-bahan yang berupa catatan, buku, surat kabar, majalah, atau bahan dokumentasi yang sifatnya tertulis (Kunto dalam Juslaeni, 2004). Dokumen merupakan catatan peristiwa yang sudah berlalu, dokumen bisa berbentuk tulisan, dalam hal ini tulisan yang dijadikan dokumen adalah Novel Sekayu karya. Sehingga dokumen dalam penelitian ini merupakan bahan-bahan penting yang digunakan untuk mengidentifikasi data-data tertulis tentang unsur intrinsik dan aspek religius kemudian mendeskripsikan sasaran sebagai penunjang pemahaman Novel Sekayu karya Nh. Dini.

\section{4 . Metode Analisis Data}

Metode yang digunakan dalam penelitian ini adalah metode deskriptif kualitatif. Penelitian deskriptif kualitatif merupakan penelitian dimana data yang dianalisis berupa deskripsi dari gejala-gejala yang diamati. Penelitian ini dimaksudkan untuk mengangkat fakta, keadaan, variabel, dan fenomena-fenomena yang terjadi saat sekarang (ketika penelitian berlangsung) dan menyajikan apa adanya. Penelitian deskriptif menuturkan dan menafsirkan data yang berkenaan dengan situasi yang terjadi dan dialami sekarang, sikap dan pandangan yang menggejala sat sekarang, hubungan antar variabel, pertentangan dua kondisi atau lebih, perbedaan-perbedaan antar fakta dan lain-lain (Subana, 2005).

Dalam tahapan analisis data ini peneliti menggunakan pendekatan struktural objektif yaitu bertumpu pada atau atas dasar karya sastra itu sendiri. Pendekatan objektif, pemahamannya dipusatkan pada analisis terhadap unsur-unsur dalam, 
dengan mempertimbangkan keterjalinan antarunsur-unsur disatu pihak dan unsurunsur dengan totalitas dipihak lain, dengan kata lain pendekatan objektif memusatkan perhatiannya pada unsur-unsur intrinsik, pendekatan objektif ini pada dasarnya bertumpu pada atau atas karya itu sendiri (Ratna, 2004). Unsur-unsur yang ada pada karya sastra itu dianalisis sehingga terlihat adanya kaitan (totalitas) antara unsur-unsur yang terkait dalam suatu cerita.

Adapun langkah-langkah yang dilakukan adalah: 1) Identifikasi data tentang aspek nilai religius yang terkandung dalam Novel Sekayu karya Nh. Dini dengan menggunakan pendekatan struktural. 2). Klasifikasi sebagaimana menurut Muhajir (1998) klasifikasi merupakan upaya mengelompokkan kembali data yang akan dianalisis. Dalam hal ini, klasifikasi data menyesuaikan dengan rumusan masalah dalam penelitian yang meliputi unsur intrinsik dan aspek religius. Keoptimalan proses klasifikasi mempermudah proses interpretasi berikutnya. Dan 3) Interpretasi, yaitu upaya pemaknaan terhadap data penelitian, yaitu mencari keterkaitan terhadap unsur yang dicermati dan menampilkan dalam suatu sajian yang deskriptif. Dalam hal ini, data yang telah diklasifikasikan tersebut dideskripsikan melalui suatu analisis terhadap keterkaitan yang dimiliki oleh data-data tersebut. Proses ini menghasilkan suatu pemaknaan yang menyeluruh terhadap data hasil penelitian.

\section{Hasil dan Pembahasan}

\subsection{Biografi pengarang}

Nh. Dini lahir 29 Februari 1936 di Semarang. Setamat SMA bagian sastra (1956), mengikuti Kursus Pramugari Darat GIA Jakarta (1956), dan terakhir mengikuti Kursus B-1 Jurusan Sejarah (1957). Tahun 1957-1960 bekerja di GIA Kemayoran, Jakarta. Setelah menikah dengan Yves Coffin, berturut-turut ia bermukim di Jepang, Prancis, Amerika Serikat, dan sejak 1980 menetap di Jakarta dan Semarang.

Karyanya: Dua Dunia (1956), Hati Yang Damai (1961), Pada (1977, 1986), Sebuah Kapal (1973, 1985), La Barka (1975), Namaku Hiroko (1977, 1986), Keberangkatan (1977, 1986), Sebuah Lorong Di Kotaku (1987), Langit dan Bumi Sahabat Kami (1979), Sekayu (1981), Amir Hamzah Pengeran Dari Seberang (1981), Kuncup Berseri 
(1984) dan Pertemuan Dua Hati (1986). Terjemahannya: Sampar (karya Albert Camus, La Peste, 1985).

Tahun 1987 Dini memenangkan hadiah pertama (untuk perserta Indonesia) lomba mengarang "meilleure de lengue francaise" yang diselenggarakan oleh Le Monde dan Radio France Internasionale.

\subsection{Analisis Aspek Religius Novel Sekayu}

Unsur ekstrinsik adalah unsur-unsur yang berada di luar karya sastra itu, tetapi secara tidak langsung mempengaruhi bangunan atau sistem organisme karya sastra. Atau secara khusus ia dapat dikatakan sebagai unsur-unsur yang mempengaruhi bangun cerita sebuah karya, namun sendiri tidak ikut menjadi bagian di dalamnya (Nurgiyantoro, 2009). Salah satu unsur ektrinsik dalam karya sastra adalah unsur religius atau keagamaan.

Istilah religius membawa konotasi pada makna agama. Religius dan agama memang berkaitan erat, berdampingan bahkan dapat melebur dalam satu kesatuan, namun sebenarnya keduanya menyaran pada makna yang berbeda. Agama lebih menunjukkan pada kelembagaan kebaktian kepada Tuhan dengan hukum-hukum yang resmi. Religiusitas di pihak lain melihat aspek yang di lubuk hati, riak getaran nurani pribadi, totalitas kedalaman pribadi manusia. Dengan demikian, religius bersifat mengatasi, lebih dalam, dan lebih luas dari agama yang tampak, formal dan resmi. Moral religius menjunjung tinggi sifat-sifat manusiawi, hati nurani yang dalam, harkat dan martabat serta kebebasan pribadi yang dimiliki oleh manusia. Dalam penelitian ini yang dikaji adalah moral religius dalam agama Islam.

Nilai-nilai moral Islami, jenis ajaran moral dalam karya fiksi sangat banyak dan bersifat tak terbatas dan hal tersebut dapat dikelompokkan ke dalam persoalan hubungan manusia dengan diri sendiri, hubungan manusia dengan sesamanya, hubungan manusia dengan alam sekitarnya dan hubungan manusia dengan Tuhannya.

Dalam Novel Sekayu karya Nh. Dini, keempat jenis hubungan tersebut tidak semuanya tercerna dalam perilaku tokoh-tokohnya. Salah satu hubungan yang tidak tercerna dalam karakteristik tokoh adalah hubungan manusia dengan alam sekitar. Hubungan manusia dengan Tuhannya kurang dapat dilihat pada sifat-sifat tokoh, 
meskipun dalam novel tersebut digambarkan tokoh dan keluarganya mengakui adanya Tuhan dan kehidupan setelah mati, dapat dilihat pada kutipan di bawah ini:

Selalu pikiran yang sama kembali setiap malam: di mana dia sekarang? Mengerjakan apa? Sebagai apa? Aku diajarkan supaya percaya akan adanya Kekuasaan Tertinggi (Dini, 2004:45).

Setelah jenazah Ayah dimandikan, kami sesaudara berenam dengan Utono, mengikuti Ibu menyembah, menciumi kaki, lutut, tangan, dan kedua pipi Ayah. Ibu berkata, bahwa Bapak sudah disucikan dan aku harus menahan air mata sekuat mungkin, agar tidak menangis dan membasahinya. Setitik air mata saja telah cukup menghambat perjalanan roh masuk syurga, kata Ibu....... Jenazah Ayah dibaringkan menghadap barat, kepala berada di sebelah Utara. Gumpalangumpalan tanah disisipkan di sana-sini. Lalu papan ditutupkan setinggi badan yang lagi duduk. Seorang tetangga yang baik hati membisikkan kepadaku, bahwa itu bermaksud supaya pada waktu malaikat datang menanyai Ayah, dia bisa bangkit duduk untuk menjawab (Dini, 2004:12).

Namun, hubungan manusia dengan Tuhannya tidak digambarkan lagi oleh pengarang melalui sikap atau perilaku tokoh. Pengarang hanya menggambarkan sedikit, tidak pada keseluruhan cerita dan menjadi sorotan. Pengarang lebih banyak menggambarkan kehidupan tokoh dalam berinteraksi dengan keluarga dan orang lain sehingga hubungan yang terlihat lebih pada hubungan manusia dengan diri sendiri dan hubungan manusia dengan sesamanya atau akhlak dari tokoh tersebut.

\subsection{Pendidikan Akhlak dalam Novel Sekayu}

Akhlak merupakan semua perbuatan yang lahir atas dorongan jiwa berupa perbuatan baik dan buruk (Al Ghazali dalam Tim Penyusun, 2003) atau akhlak adalah tingkah laku, budi pekerti, yang melekat pada jiwa seseorang untuk melakukan suatu hal atau perbuatan. Berikut adalah akhlak baik (akhlakul kharimah) yang patut dijadikan pembelajaran dalam kehidupan sehari-hari yang diperlihatkan tokoh pada Novel Sekayu karya Nh. Dini yang berlandaskan agama.

Dalam Islam pendidikan akhlak adalah diantara pendidikan yang utama dan pertama yang harus diberikan kepada anak didik setelah tauhid, dalam al-Qur'an sebagai pedoman umat Islam hal tersebut cukup banyak menjelaskan selain berupa hadits-hadits dari Nabi Muhammad SAW. Akhlak sangat berkorelasi dengan akidah bahkan tidak sedikit hadits yang secara ekplisit menjelaskan bahwa tidak beriman/ 
berakidah orang yang tidak amanah. Sementara amanah adalah bagian dari akhlakul karimah.

Sehubungan dengan hal tersebut di atas maka dalam novel Sekayu karya $\mathrm{NH}$ Dini, pendidikan akhlak yang terdapat di dalamnya adalah:

\section{a. Akhlak terhadap keluarga}

Salah satu akhlak terhadap keluarga yang digambarkan pengarang dalam Novel Sekayu adalah pengabdian/berbakti kepada orang tua. Dalam agama Islam dijelaskan sebagai birrul walidain. Dalam Al qur'an dijelaskan pada surat An-Nisaa' ayat 36, yang berbunyi:

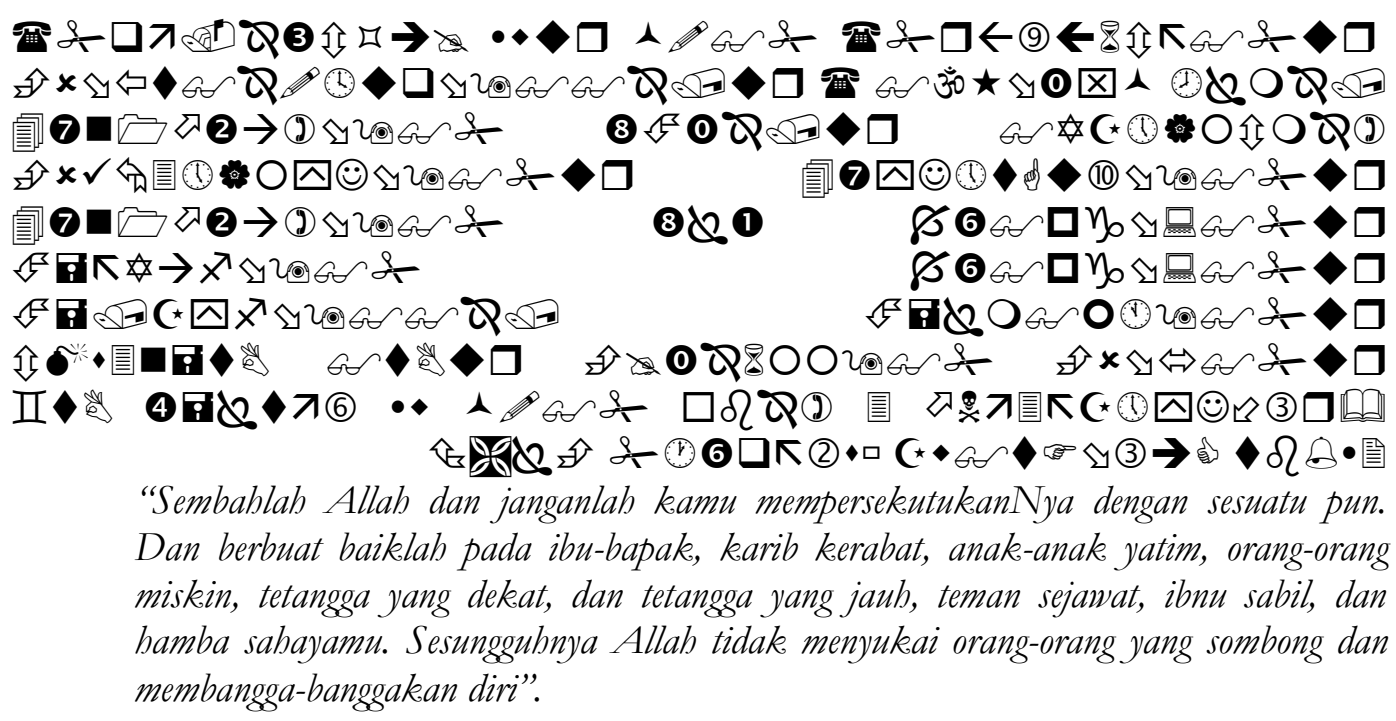

Pada novel ini diceritakan bagaimana tokoh Dini turut membantu kesusahan yang dihadapi ibunya dengan ikut lomba mengarang dan sebagainya agar beban yang dipikirkan ibunya berkurang. Tokoh Dini juga selalu menjunjung ajaran yang diajarkan oleh kedua orang tuanya di setiap langkah perjalanan hidupnya, menjadi pedoman hidupnya untuk mendapat yang lebih baik. Berbakti kepada orang tua dan mematuhi segala perintahnya merupakan ajaran agama yang harus dipatuhi oleh setiap manusia.

Hal ini sejalan dengan pendidikan Lukmanul Hakim kepada anaknya. telah di gambarkan dalam al-Qur'an Surat Luqman ketika memberi pelajaran kepada anaknya. Adapun pelajaran pertama yang diberikan oleh Lukmanul Hakim setelah tauhid adalah akhlak. Akhlak dengan cakupan yang sangat luas antara lain bagaimana 
bersabar dan bersyukur dan akhlak kepada Allah, dalam hal ini Lukmanul Hakim mendidik anaknya dengan mendirikan shalat. Kemudian akhlak kepada kedua orang tua, ia mengajarkan cara-cara berbakti sekalipun kedua orang tua berbeda akidah tetap berbakti kepada keduanya, itulah pendidikan Lukman Hakim kepada anaknya yang diuraikan al-Qur'an. Tentang wajibnya berbakti keepada kedua orang tua walau dalam kondisisi berbeda akidah. QS Lukman ayat 14-15 dengan lugas menyatakan yang artinya :

Dan kami perintahkan kepada manusia (berbuat baik) kepada dua orang ibubapanya; ibunya Telah mengandungnya dalam keadaan lemah yang bertambah- tambah, dan menyapihnya dalam dua tahun. bersyukurlah kepadaku dan kepada dua orang ibu bapakmu, Hanya kepada-Kulah kembalimu. Dan jika keduanya memaksamu untuk mempersekutukan dengan Aku sesuatu yang tidak ada pengetahuanmu tentang itu, maka janganlah kamu mengikuti keduanya, dan pergaulilah keduanya di dunia dengan baik, dan ikutilah jalan orang yang kembali kepada-Ku, Kemudian hanya kepada-Kulah kembalimu, Maka Kuberitakan kepadamu apa yang telah kamu kerjakan.

\section{b. Akhlak terhadap diri sendiri}

Dalam Novel Sekayu karya Nh. Dini digambarkan sifat tokoh dini dan Ibu yang selalu sabar dan tabah dalam menghadapi ujian yang diberikan Tuhan kepada keluarga mereka. Sabar merupakan salah satu akhlak terhadap diri sendiri (Tim Penyusun, 2003). Dalam Al Qur'an dijelaskan pada surat Al-Baqarah ayat 153 yang berbunyi:

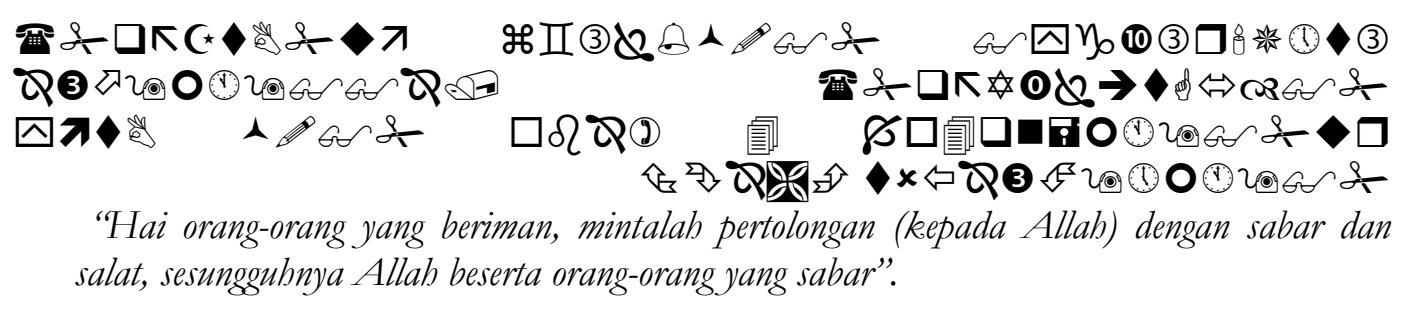

Kesabaran tokoh Ibu dapat dilihat pada kutipan cerita di bawah ini:

Dengan sedih dan tangan hampa, Ibu pulang. Dan dia tidak ingin hal itu dibicarakan lagi, karena hanya akan mencukil-cukil kesakitan hati (Dini, 2004: 43)

Meskipun dalam keadaan lelah dan tidak mendapatkan hasil yang diinginkan, Ibu tetap sabar dan berusaha tegar. 
Pada kutipan di bawah ini juga digambarkan kesabaran dari tokoh Dini dalam menerima ketentuan Allah:

Untuk kesekian kalinya aku dihadapkan oleh hidup yang masih begitu pendek kepada persoalan bagaimana bergaul dengan pihak lawan jenisku. Dan untuk kesekian kalinya pula kesedihan atau persoalanku bertambah. Aku berusaha terus berjalan dengan kepala tegak, dengan tersenyum, sebagaimana ajaran orang tua kami (Dini, 2004:168).

Dari kutipan di atas menunjukkan bahwa dalam novel ini juga mempunyai nilai yang mengajarkan kita menjadi orang yang sabar dan berjiwa besar dalam menghadapi cobaan.

\section{c. Akhlak Terhadap Masyarakat}

1. Tolong menolong

Agama Islam mengajarkan manusia untuk selalu tolong menolong antarsesama. Hal tersebut karena manusia yang tidak bisa hidup sendiri tanpa bantuan dari orang lain. Salah satu bentuk tolong menolong adalah tolong menolong dalam kehidupan bertetangga, karena tetangga dapat diibaratkan saudara setelah keluarga yang berada di sekitar kita dan selalu berinteraksi dengan kita. Agama Islam juga mengajarkan untuk saling tolong menolong tanpa mengharap pamrih, imbalan atau pujian atas jasa yang kita lakukan. Dalam Al Qur'an surat Al-Maidah ayat 2 dijelaskan mengenai tolong menolong:

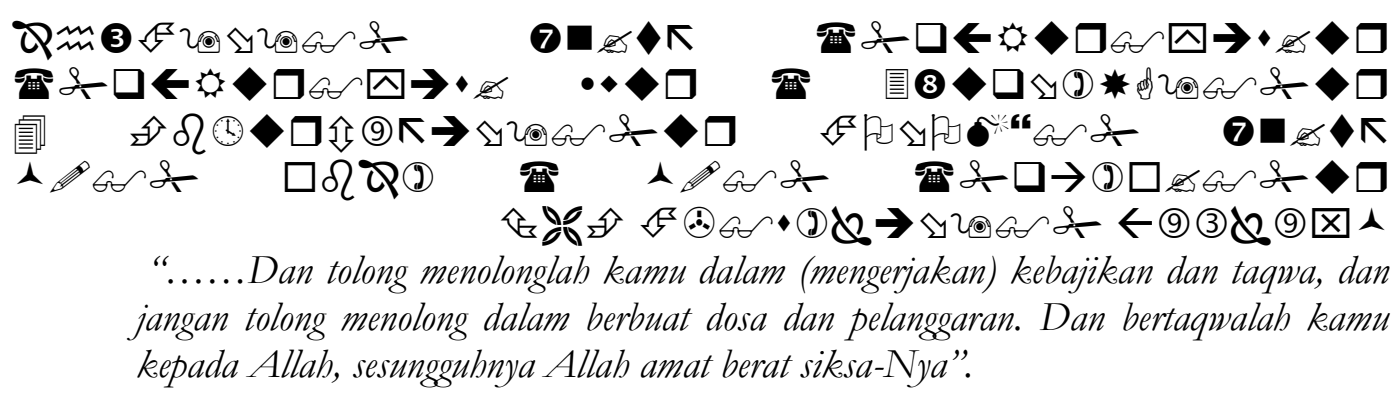

Dalam kutipan di bawah ini, diperlihatkan sifat Dini dan keluarga yang selalu menolong tetangga sekitar yang membutuhkan bantuan:

Dirga mengantar sampai ke hangar sepeda kami meneruskan berbicara mengenai cintanya. Dia hendak mengirimkan surat berisikan kerinduannya kepada si gadis. Dia tidak tahu bagaimana menulis kalimat-kalimat yang merayu hati.

"Kalau kau mempunyai sajak-sajak mengenai perasaan cinta, dapatkah aku memintanya?” 
Harus kutulis yang baru," kataku. "Yang dulu-dulu sudah terjual ke RRI atau Gajah Mada. Tidak jujur kalau dipergunakan lagi."

"Kau bisa membikin untukku?"

"Tentu saja."

Berdasarkan kutipan di atas, dipaparkan sifat suka menolong dari tokoh Dini. Sebenarnya Dini bisa saja tidak menerima permintaan Dirga karena merasa sakit hati cintanya tak disambut dan malah diminta membuat sajak untuk wanita lain yang disukainya.

Dalam kutipan di bawah ini juga diperlihatkan sifat Dini yang suka menolong dan kepedulian Dini terhadap masyarakat sekitarnya. Dini membantu warga yang tidak bisa membaca dan membimbing mereka agar bisa membaca dan menulis tanpa mengharap imbalan:

Tiba-tiba aku tertarik akan tugas itu. Barangkali juga karena ajakan Pung yang demikian bersemangat. Dan sejak kesempatan berikutnya aku menjadi anak buah Pak Puspo. Di tempat-tempat lain dalam kampung kami terdapat kelaskelas buta huruf semacam itu.......Lalu diam-diam bersama Pung, aku mengunjungi pondok-pondok di gang itu. Kami berbicara dengan ibu-ibu, baik tua maupun muda, bertanya apakah mereka tidak ingin berusaha mengenal huruf agar bisa membaca sedikit. Kukatakan pula bahwa tentulah mereka akan merasa bangga jika dapat mengerti apa yang tertulis di papan-papan pengumuman misalnya. Dapat membaca amat penting. Kadang-kadang dapat mendahului orang lain mengetahui sesuatu berita. Seharusnya kaum wanita juga sanggup menunjukkan bahwa meskipun setua suami atau saudara mereka, tetapi masih akan dapat belajar dengan baik (Dini, 2004:51).

2. Penyantun

Penyantun dalam KBBI berarti peramah, baik budi bahasanya. Menurut pengertian agama, penyantun adalah orang yang memiliki budi pekerti, sikap dan tutur kata yang baik. Dalam Agama Islam diajarkan setiap manusia untuk selalu berbuat baik kepada sesamanya. Dalam Al Qur'an dijelaskan pada Surat Ali Imran ayat 133-134 yang artinya:

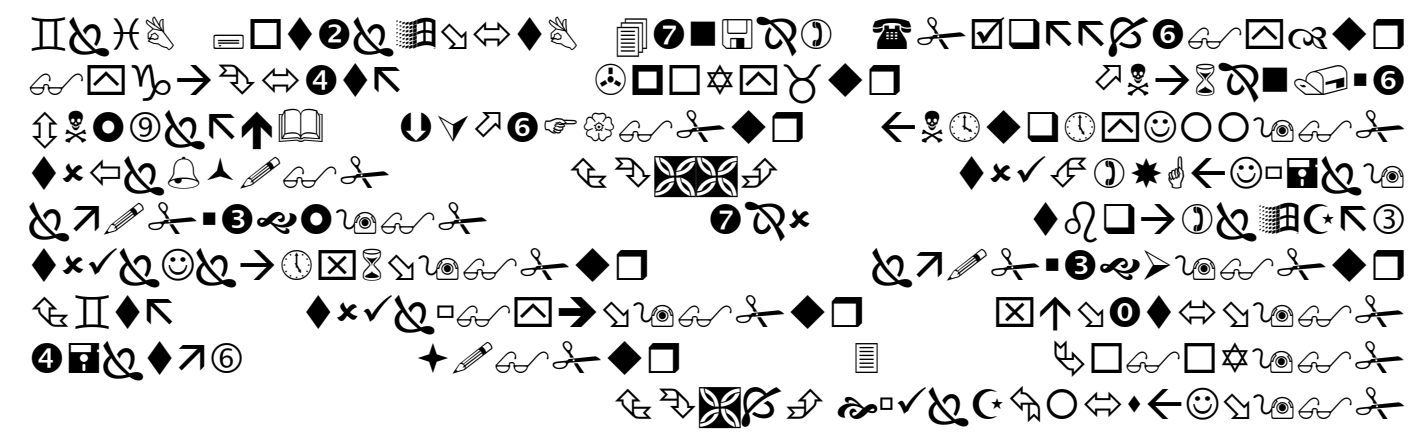


"Dan bersegeralah kamu kepada ampunan dari Tuhanmu dan kepada surga yang luasnya seluas langit dan bumi yang disediakan untuk orang-orang yang bertaqwa. Yaitu orangorang yang menafkabkan (hartanya), baik di waktu lapang maupun sempit, dan orangorang yang menahan amarahnya dan memaafkan kesalahan orang. Allah menyukai orangorang yang berbuat baik".

Pada kutipan di bawah ini digambarkan sifat dermawan Ibu:

Perempuan tua ini amat menyayangiku. Sejak masa kecilku, aku selalu memintanya sebagai penjual nasi pecel dan minuman es beserta ramuan buahbuahan. Dia menyaksikan beberapa anak kampung tumbuh besar. Di antaranya aku. Kurasakan kesayangannya yang berlebih-lebihan. Barangkali disebabkan oleh sikap orang tuaku, terutama Ibu, yang selalu dermawan kepadanya. Ibu tidak pernah lupa mengirimkan sebagian rezeki yang diperolehnya kepada perempuan itu, baik berupa hasil kebun, uang, pakaian maupun bahan makanan lain. Di masa-masa sukar, kebiasaan itu tetap dilakukan (Dini, 2004: 33).

Dari kutipan di atas menunjukkan bahwa dalam Novel Sekayu ini juga kita diajarkan untuk selalu menolong tetangga yang sedang kesusahan dan menafkahkan sebagian rezeki yang kita punya kepada mereka yang membutuhkan.

Kutipan tersebut juga sangat relevan dengan apa yang diajarkan dalam Islam dan telah disabdakan oleh nabi Muhammad SAW dalam haditsnya bahwa siapa yang benar-benar beriman kepada allah dan Rasulnya maka hendaklah ia memuliakan tetangga. Hadits tersebut juga dapat dipahami bahwa orang yang memuliakan tetangga adalah termasuk di antara orang yang telah memiliki aqidah yang kuat.

\section{Penutup}

\subsection{Simpulan}

Berdasarkan hasil analisis dan pembahasan maka dapat dibuat kesimpulan bahwa: Aspek religius yang diangkat dalam Novel Sekayu adalah moral religius dalam agama Islam, yakni akhlak yang menjunjung tinggi sifat-sifat manusiawi, hati nurani yang dalam, harkat dan martabat serta kebebasan pribadi yang dimiliki oleh manusia, di antaranya: akhlak terhadap diri sendiri (sabar dan tabah dalam menerima ketentuan Tuhan), akhlak terhadap keluarga (berbakti kepada orang tua), akhlak terhadap masyarakat (tolong menolong, penyantun dan budi pekerti yang baik).

\subsection{Saran}

Adapun saran-saran yang yang dapat diajukan adalah: 
1. Penelitian ini merupakan sebagian kecil dari sebuah permasalahan yangterdapat dalam novel sekayu karya NH Dini, oleh karenaitu penelitian selanjutnya mengenai aspek- aspek yang lain sangat perlu dilakukan.

2. Bagi pembaca, agar bisa mengambil hikmah dari pesan yang terkandung dalam setiap karya sastra yang dapat berguna bagi kehidupan.

\section{Daftar Pustaka}

Abbas, Sirojuddin, 2004. I'tiqad Ablus-Sunnah Wal Jama'ah, Jakarta, Pustaka Tarbiyah. Alwi, Hasan. 1994. KBBI Edisi Kedua. Jakarta: Balai Pustaka.

Aminuddin. 1995. Pengantar Apresiasi Karya Sastra. Malang: Sinar Baru

Amin, Mansyur. 2002. Aqidah Dan Syariah Islam. Jakarta: Bumi Pustaka.

Arikunto, Suharsimi. 1998. Prosedur Penelitian Suatu Pendekatan Praktek. Jakarta: Rineka Cipta.

Badrun, Ahmad. 1983. Pengantar Ilmu Dan Sastra. Surabaya: Usaha Nasional.

Dini, Nh. 1979. Sekayu. Jakarta: PT. Gramedia Pustaka Utama.

Harahap, Syahrian, 2002. Metode Penelitian Ilmu-Ilmu Ushuludin, Jakarta, Bulan Bintang

Kejono, Imam. 1996. Nilai-Nilai Religiusitas Dalam Sastra Lampung. Jakarta: Pusat Pembinaan Dan Pengembangan Bahasa DEPDIKBUD.

Kusdiratin. 1983. Struktur Dan Makna Pabrik, Telegram, Stasiun Karya Putu Wijaya (tesis). Mataram: Perpustakaan Unram.

Muhajir, Neong. 1998. Metode Penelitian Kualitatif. Yogyakarta: Ruke Sarasin.

Nurdin, Muslim dkk. 1995. Moral Dan Kognisi Islam. Bandung: Alfabeta.

Nurgiyantoro., Burhan. 2009: Teori Pengkajian Fiksi. Yogyakarta: UGM Press.

Ratna, Nyoman Kutha. 2004. Teori, Metode Dan Teknik Penelitian Sastra. Yogyakarta: Pustaka Pelajar.

Ratnawati, Risty dkk. 2002. Religiusitas Dalam Sastra Jawa Modern. Jakarta: Pusat Bahasa Departemen Pendidikan Nasional.

Salim, Peter dan Yenny Salim. 1991. Kamus Bahasa Indonesia Kontemporer. Edisi Pertama. Jakarta: Modern English Press.

Subana. 2005. Dasar-Dasar Penelitian Ilmiah. Bandung: Pustaka Setia.

Tarigan, Henry Guntur. 1991. Prinsip-Prinsip Dasar Sastra. Bandung: Angkasa. 
Tim Penyusun. 2003. Pendidikan Agama Islam. Jakarta: Pusat Penerbitan Universitas Terbuka.

Zulfahnur dkk. 1996. Teori Sastra. Departemen Pendidikan dan Kebudayaan Direktorat Jenderal Pendidikan Dasar dan Menengah Bagian Proyek Penataran Guru SLTP Setara D-III Mataram: Perpustakaan FKIP Unram. 